DOI: doi.org/10.21009/AKSIS.030215

$\begin{array}{ll}\text { Received } & : 20 \text { March } 2019 \\ \text { Revised } & : 29 \text { March } 2019 \\ \text { Accepted } & : \text { 12 September } 2019 \\ \text { Published } & : 27 \text { Desember } 2019\end{array}$

\title{
Acronym Formation Study in Waspada Medan Daily Newspapers
}

\author{
Alkaushar Lingga ${ }^{1, a)}$, Edi Yanto ML ${ }^{1, b)}$, Susy Deliani ${ }^{1, c)}$ \\ 1 \\ Universitas Muslim Nusantara Al-Washliyah Medan \\ pos-el: ${ }^{a)}$ suratsyair@gmail.com
}

\begin{abstract}
This study examines the process of making an acronym in the Waspada daily newspaper Medan published on 1, 4 and 6 April 2019. The purpose of this study is to describe the process of forming an acronym in the Waspada Medan daily newspaper published on 1, 4 and 6 April 2019. This research method is a descriptive qualitative method. The research data is sourced from the Waspada Medan daily newspaper on 1, 4, and 6 April 2019. Techniques for collecting data with techniques refer to and are accepted. The results of this study describe the five patterns of the formation of acronyms, namely: (1) Tribal sequencing with tribes, (2) sequencing of tribes with tribes and letters, (3) sequencing of words with tribes and letter, (4) impingement of words with terms and letters, and (5) initial letter.
\end{abstract}

Keywords: acronyms, process, formation, waspada

\begin{abstract}
Abstrak
Penelitian ini mengkaji tentang proses pembentukan akronim pada surat kabar harian Waspada Medan terbitan tanggal 1, 4 dan 6 April 2019. Tujuan penelitian ini untuk mendeskripsikan proses pembentukan akronim pada surat kabar harian Waspada Medan terbitan tanggal 1, 4 dan 6 April 2019. Metode penelitian ini menggunakan metode kualitatif deskriptif. Data penelitian ini bersumber dari surat kabar harian Waspada Medan tanggal 1, 4, dan 6 April 2019. Teknik pengumpulan data dengan teknik membaca dan mencatat. Hasil penelitian ini mendeskripsikan lima pola proses pembentukan akronim yaitu: (1) Pengekalan suku dengan suku, (2) Pengekalan suku dengan suku dan huruf, (3) Pengekalan kata dengan suku dan huruf, (4) Pelesapan kata dengan suku dan huruf, dan (5) Pengekalan huruf awal.
\end{abstract}

Kata kunci: akronim, proses, pembentukan, waspada 


\section{PENDAHULUAN}

Bahasa merupakan alat penting berkomunikasi dalam setiap sendi kehidupan manusia. Tanpa bahasa kehidupan bisa rumit dan tidak berjalan sebagaimana yang diharapkan. Pentingnya bahasa sudah dimulai ketika manusia lahir ke muka bumi ini. Bahkan tanpa bahasa ilmu pengetahuan yang canggih tidak akan mampu dipelajari, diajarkan serta dipahami oleh manusia.Keutamaan bahasa sangat perlu diindahkan sesuai dengan fungsi dan kaidah bahasa tersebut. Setiap kata memiliki arti dan makna tersendiri yang telah disepakati oleh masyarakat sebagai pengguna bahasa. Termasuk pola bahasa yang telah ada atau sedang berkembang di masyarakat.

Bahasa selalu bekerja sebagai medium yang tepat dalam setiap komunikasi kehidupan manusia. Setiap profesi apapun sangat membutuhkan bahasa sebagai penunjang aktivitas kerja. Bahasa memiliki peran penting pada peningkatan karir setiap profesi dengan penggunaan bahasa yang terampil, efektif, dan tepat (Purwanto \& Markhamah, 2019). Dalam Depdiknas (2013) bahasa merupakan sistem lambang bunyi yang arbiter, yang digunakan oleh anggota suatu masyarakat untuk bekerja sama, berinteraksi, dan mengidentifikasikan diri. Sedangkan menurut Kridalaksana (1996) mengatakan, bahasa adalah sistem lambang bunyi bermakna yang digunakan untuk berkomunikasi oleh kelompok manusia.

Perkembangan bahasa memang selalu terjadi di masyarakat, sebab itu ilmu bahasa disebut sebagai ilmu yang bersifat dinamis. Proses dan latar belakang perkembangan bahasa ini juga dipengaruhi oleh banyak hal. Baik dari proses psikologi, sosiologi, dan lain sebagainya. Tentu perkembangan bahasa dimaksud disini dari istilah baru atau pun singkatan maupun akronim.

Pada era milineal ini kosakata bahasa indonesia banyak didapati istilah baru atau akronim dalam berbahasa. Akronim baru tersebut muncul sebab kreativitas bahasa yang dibuat oleh pengguna bahasa. Kreativitas tersebut hadir akibat perkembangan zaman yang serba canggih dan modern. Akronim hadir untuk memenuhi kebutuhan berbahasa untuk tetap menunjukkan eksistensi dalam masyarakat.

Perkembangan akronim bukan hanya terjadi secara lisan tetapi juga dalam tulisan baik di media cetak dan media sosial. Munculnya akronim baru untuk kebutuhan berkomunikasi antar sesama masyaraka agar efektif dan efisien. Perkembanganbahasa penting dipelajari dan dikaji termasuk akronim menarik diteliti dalam harian media massa untuk memahami bagaimana pembentukan akronim. Pemahaman tentang pembentukan akronim sangat penting agar masyarakat bahasa memiliki pengetahuan membuat akronim sesuai pola bahasa yang berterima.

Sesuai dengan tujuan pendidikan untuk mencerdaskan bangsa maka penelitian mengenai akronim ini sangat penting untuk dikaji. Sebab akronim baru ini sering muncul dalam pengguna bahasa saat berkomunikasi. Namun, perjalanannya masih banyak akronim belum memiliki proses pembentukan terbaru. Penggunaan akronim yang sesuai kaidah sangat penting disosialisasikan demi kepentingan keutuhan bahasa indonesia.

Surat kabar menjadi media yang sangat efektif menyebar luaskan informasi kepada setiap lapisan masyarakat. Setiap istilah bahasa seperti akronim yang terdapat dalam surat kabar harian menjadi mudah diketahui oleh pembaca. Surat kabar dan 
majalah menguasai masyarakat dengan berita-beritanya, dengan segala macam informasi, opini,serta tulisan-tulisan yang bersifat hiburan. Itu sebabnya surat kabar mendapat julukan "Ratu Dunia”. (Badudu, 1993).

Harian Waspada yang terbit di medan merupakan salah satu surat kabar tertua di Sumatra Utara. Wartawan yang meliput berita untuk harian Waspada juga meliputi Sumatra Utara baik kabupaten dan kota, Provinsi Aceh dan memiliki perwakilan di Jakarta. Dari segi pemberitaan harian Waspada berisi berita yang aktual. Berdasarkan hasil penelitian oleh Nielsen tahun 2010 pembaca surat kabar harian Waspada mencapai angka 73.000 orang per hari.

Edisi yang diteliti pada penelitian ini pada hari dan tanggal senin 1 karena pada hari senin iniberisi berita dalam surat kabar hangat dan menarik serta juga ada rubrik opini. Kemudian pada hari kamis tanggal 4 yaitu pertengahan pekan, tentunya pada tengah pekan sering bermunculan berita yang terbaru dan segar serta menyediakan berita universitaria. Dan pada edisi hari sabtu tanggal 6, pada akhir pekan biasa berita ekonomi, bisnis, olahraga dan rangkuman berita selama sepekan. Hal tersebut menjadi acuan dalam pemilihan edisi terbit sebagai data penelitian.

Penelitian ini bertujuan untuk mengetahui proses pembentukan akronim yang terdapat pada surat kabar harian Waspada Medan terbitan tanggal 1, 4 dan 6 tahun april 2019. Proses pembentukan akronim ini diteliti sesuai data yang ada dari akronim dari harian Waspada Medan. Data yang ada akan dikelompokkan dengan proses pembentukan sesuai pola pembentukan akronim yang telah berterima sebagaiman menurut pendapat ahli dan penelitian terdahulu.

Morfologi bagian dari linguistik umum yang mempelajari tentang bentuk bahasa. Chaer (2008) mengatakan, secara etrimologi kata morfologi berasal dari kata morf berarti bentuk dan kata logi yang berarti ilmu. Jadi secara harfiah kata morfologi berarti ilmu yang mengenai bentuk'. Dalam linguistik morfologi berarti 'ilmu yang mempelajari bentuk-bentuk dan pembentukan kata'.

Bauer dalam Deliani (2013) mengatakan, morfologi membahas struktur internal bentuk kata. Dalam morfologi, analisis membagi bentuk kata ke dalam formatif komponennya (yang kebanyakan merupakan morf yang berwujud akar kata atau afiks) dan berusaha untuk menjelaskan kemunculan setiap formatif. Morfologi dapat dibagi ke dalam dua cabang utama, yaitu morfologi infleksional dan pembentukan kata yang disebut morfologi leksikal.

Morfologi ini kata yang dipinjam dari ilmu biologi tentang pemebntukan tubuh hewan. Dalam dilnguistik kata morfologi diartikan sebagai pembentukan kata. Kata dalam bahasa bisa berdiri sendiri dan untuk mengartikan makna lain dibutuhkan kata tambahan seperti morfem. Dalam berbahasa tentu berawal dari kata-kata yang dipakai untuk membentuk kalimat dalam menyampaikan pesan. Proses pembentukan kata ini tentu bukan saja berproses seperti air mengalir tetapi memiliki pola berkesesuaian dalam bahasa Indonesia.

Chaer (2008) mengatakan proses morfologi adalah pembentukan kata dari sebuah bentuk dasar melalui pembubuhan afiks (dalam proses afiksasi), pengulangan (dalam proses reduplikasi), penggabungan (dalam proses komposisi). Pemendekan (dalam proses akronimisasi) dan pengubahan status (dalam pengubahan konversi). 
Proses morfologi ini melibatkan beberapa komponen seperti komponen 1) bentuk dasar 2) alat pembentuk termasuk didalamnya (afiksasi, reduplikasi, komposisi, akaronimisasi, dan konversi) 3), makna gramatikal, dan 4) hasil; proses pembentukan.

Istilah merupakan kata yang digunakan untuk menyebut sesuatu hal dalam berbahasa. Waridah (2016) isitilah adalah kata atau frasa yang dipakai sebagai nama atau lambang dan yang dengan cermat mengungkapkan makna, konsep, proses, keadaan atau sifat yang khas dalam bidang ilmu pengetahuan, teknologi, dan seni. Tata istilah (terminologi) adalah perangkat asas dan ketentuan pembentukan istilah serta kumpulan istilah yang dihasilkannya.

Istilah umum adalah istilah yang berasal dari bidang tertentu, yang karena dipakai secara luas, menjadi unsur kosakata umum misalnya nikah dengan takwa.Istilah khusus adalah isitilah yang maknanya terbatas pada bidang tertentu saja misalnya isalnya apendektomi dengan kurtosis atau bipatride dengan pleistosen.

Dalam berbahasa sangat memperhatikan aspek santun dan benar agar bahasa tersebut berfungsi baik. Istilah-istilah berbahasa dipakai untuk menjaga agar kesantunan tetap terjaga. Berikut syarat istilah berbahasa yang santun dan benar yaitu istilah yang dipilih adalah kata atau frase yang paling tepat untuk mengungkapkan konsep termaksud dan yang tidak menyimpang dari makna itu istilah yang dipilih adalah kata atau frase yang paling singkat diantara pilihan yang tersedia yang mempunyai rujukan yang sama, istilah yang dipilih adalah kata atau frase yang bernilai rasa (konotasi) baik, istilah yang dipilih adalah kata atau frase yang sedap didengar (eufonik), istilah yang dipilih adalah kata atau frase yang bentuknya seturut kaidah bahasa Indonesia.

Upaya kecendikiaan ilmuan (scientist) dan pandit (scholar) telah dan terus menghasilkan konsep ilmiah, yang pengungkapannya dituangkan dalam perangkat peristilahan. Ada istilah yang mapan dan ada pula isitilah yang masih perlu diciptakan. Konsep ilmiah yang sudah dihasilkan ilmuan dan pandit Indonesia dengan sendirinya mempunyai istilah yang mapan. Akan tetapi, sebagian besar konsep ilmu pengetahuan modern yang dipelajari, digunakan, dan dikembangkan oleh pelaku ilmu pengetahuan dan teknologi di Indonesia datang dari luar negeri dan sudah dilambangkan dengan istilah bahasa asing. Di samping itu, ada kemungkinan bahwa kegiatan ilmuan dan pandit Indonesia akan mencetuskan konsep ilmu pengetahuan, teknologi, dan seni yang sama sekali baru sehingga akan diperlukan penciptaan istilah baru.

Tidak ada satu bahasa pun yang sudah memiliki kosakata yang lengkap dan tidak memerlukan ungkapan untuk gagasan, temuan, atau rekaciptanya yang baru. Bahasa Inggris yang kini dianggap bahasa internasional utama, misalnya, pernah menyerap kata dan ungkapan dari bahasa Yunani, Latin, Prancis dan bahasa lain, yang jumlahnya hampir tiga perlima dari seluruh kosakataya. Sejalan dengan itu bahan isitilah Indoensia diambil dari berbagai sumber terutama dari tiga golongan bahasa yang penting,yakni (1) bahasa Indonesia, termasuk unsur serapannya, dan bahasa melayu, (2) bahasa Nusantara yang serumpun, termasuk bahasa Jawa Kuno, dan (3) bahasa asing, seperti bahasa Inggris dan bahasa Arab.

Pemadanan istilah asing ke dalam bahasa Indonesia, dan jika perlu ke salah satu bahasa serumpun, dilakukan lewat penerjemahan, penyerapan, atau gabungan penerjemahan dan penyerapan. Demi keseragaman sumber rujukan yang diutamakan adalah istilah inggris yang pemakaiannya bersifat internasional karena sudah dilazimkan 
oleh para ahli dalam bidangnya. Penulisan istilah serapan itu dilakukan dengan atau tanpa penyesuaian ejaaannya berdasarkan kaidah fonotaktik, yakn urutan bunyi yang diizinkan dalam bahasa Indonesia.

Istilah dapat berupa (1) bentuk dasar (2) bentuk berafiks, (3) bentuk ulang, (4) bentuk majemuk, (5) bentuk analogi, (6) hasil metanalisis, (7) singkatan, (8) akronim. Chaer (2008) mengatakan, akronimisasi adalah proses pembentukan sebuah kata dengan menyingkat sebuah konsep yang direalisasikan dalam sebuah kontruksi lebih dari sebuah kata. Proses ini menghasilkan sebuah kata yang disebut akronim.

Depdiknas (2013) menjelaskan, akronim merupakan kependekan yang berupa gabungan huruf atau suku kata atau bagian lain yang ditulis dan dilafalkan sebagai kata yang wajar (misal letkol letnan kolonel, rudal peluru kendali, dan kowani, kongres wanita indonesia). Sesuai penjelasan tersebut Kridalaksana (1996:169) mengatakan, bila seluruh kependekan itu dilafalkan sebagai kata yang wajar, maka kependekan itu merupakan akronim.

Nugraheni (2017) menjelaskan bahwa, akronim adalah bentuk yang diambil dari sebuah frasa. Susunan akronim bervariasi ada akronim berbentuk dari (1) suku kata pertama satker yaitu satuan kerja (2) suku kata pertama ditambah tiga huruf berikutnya koramil yaitu komandan rayon militer (3) suku pertama ditambah suku kata berikutnya contoh kemendikbud kementerian pendidikan dan kebudayaan

Depdiknas (2016) membagi akronim dalam tiga hal seperti berikut: (a) akronim nama diri yang terdiri atas huruf awal setiap kata ditulis dengan huruf kapital tanda titik. Contoh BIG Badan Informasi Geospasial dan LIPI Lembaga Ilmu Pengetahuan Indonesia (b) Akronim nama diri yang berupa gabungan suku kata atau gabungan huruf dan suku kata dari deret kata ditulis dengan huruf awal kapital. Yakni Bulog Badan Urusan Logistik dan Bappenas merupakanBadan Perencanaan Pembangunan Nasional (c) Akronim bukan nama diri yang berupa gabungan huruf awal dan suku kata atau gabungan suku kata ditulis dengan huruf kecil. Yaitu iptek merupakanilmu pengetahuan dan teknologi dan pemilu pemilihan $u$ mum

Akronim adalah singkatan yang berupa gabungan huruf awal, gabungan suku kata atau gabungan huruf, dan suku kata dari deret kata yang diperlukan sebagai kata (Moeliono, Alwi, dkk., 1998 dalam Zaim (2015). Selanjutnya, Moeliono (1998) juga menjelaskan, dalam membentuk akronim perlu diperhatikan syarat-syarat berikut: (1) jumlah suku kata akronim jangan melebihi jumlah suku kata indonesia yang lazim, dan (2) akronim dibentuk dengan mengindahkan keserasian kombinasi vokal, dan konsonan yang sesuai dengan pola kata indonesia yang lazim.

Menurut Kridalaksana (1996) akronim mempunyai sub klasifikasi sebanyak 16 tipe dengan proses pengekalan suku, huruf suku dan huruf yang sukar dirumuskan. Sebagai pegangan dapat ditentukan bahwa bila seluruh kependekan itu dilafalkan sebagai kata yang wajar, kependekan itu merupakan akronim. (1) Pengekalan suku pertama dari tiap komponen contoh Orba, (2) pengekalan suku pertama komponen pertama dan pengekalan kata seutuhnya contohBanstir, (3) Pengekalan suku kata terakhir dari tiap komponen contoh gatrik tenaga listrik.(4) Pengekalan suku pertama dari komponen pertama dan kedua serta huruf serta huruf pertama dari komponen selanjutnya contoh, Gapani, (5) Pengekalan suku pertama tiap komponen dengan pelepasan konjungsi contoh, Anpuda, (6) Pengekalan huruf pertama tiap komponen 
contoh, KONI, (7) Pengekalan huruf pertama tiap komponen frase dan pengekalan dua huruf pertama komponen terakhir contoh Aika, (8) Pengekalan dua huruf pertama tiap komponenUnud, (9) Pengekalan tiga huruf pertama tiap komponen contoh Komrad, (10) Pengekalan dua huruf pertama komponen pertama dan tiga huruf pertama komponen kedua disertai pelepasan konjungsi:Abnon, (11) Pengekalan dua huruf pertama komponen pertama dan ketiga serta pengekalan tiga huruf pertama komponen kedua, contoh Neokolim, (12) Pengekalan tiga huruf pertama komponen pertama dan ketiga serta pengekalan huruf pertama komponen ke dua contoh Nasakom, (13) Pengekalan tiga huruf pertama tiap komponen serta pelepasan konjungsiFalsos, (14) gekalan dua huruf pertama komponen pertama dan tiga huruf pertama komponen kedua contohJabar, (15)Pengekalan empat huruf pertama tiap komponen disertai pelepasan konjungsiAgitrop, (16)Pengekalan berbagai huruf dan suku kata yang sukar dirumuskan, contoh Akaba.

Deliani (2013) mengatakan, akronim adalah singkatan yang diberlakukan sebagai kata. Akronim merupakan fenomena yang universal dan terdapat pada semua bahasa. Deliany (2013) menemukan enam pola pembentukan akronim. Klasifikasi enam pola pembentukan akronim tersebut yaitu (I) Pengekalan suku dengan suku memiliki sepuluh proses pengekalan (II) Pengekalan suku dengan suku dan huruf memiliki lima puluh delapan proses pengekalan (III) Pengekalan kata dengan suku dan huruf memiliki lima proses pengekalan (IV) Pelesapan suku dan hurufmemiliki empat proses pengekalan (V) Pengekalan huruf awal memiliki tiga proses pengekalan, dan (VI) Pengekalan huruf awal dengan suku memiliki tiga proses pengekalan.

\section{METODE PENELITIAN}

Penelitian akronim ini menggunakan metode penelitian kualitatif deskriptif. Aminuddin dalam Sirait (2015) mengatakan, Metode kualitatif deskriptif merupakan prosedur penelitian yang menghasilkan data deskriptif berupa uraian. Metode kualitatif deskriptif yang dianalisis dan hasil analisis berbentuk deskripsi tidakberupa angkaangka atau koefisien tetang hubungan antar variabel.

Bogdan dan Taylor dalam Moleong (2010) mengatakan, metodologi kualitatif sebagai prosedur penelitian yang menghasilkan data deskriptif berupa kata-kata tertulis atau lisan dari orang-orang dan perilaku yang dapat diamati. Sejalan dengan defenisi tersebut, Kirk dan Miller dalam Moleong (2017) mendefenisikan, penelitian kualitatif adalah tradisi tertentu dalam ilmu pengetahuan sosial yang secara fundamental bergantung pada manusia baik dalam kawasannya maupun peristilahannya.

Penelitian ini akan dianalisis menggunakan pola pembentukan akronim sesuai dengan teori Deliani (2013). Data dalam penelitian ini adalah akronim yang terdapat dalam berita harian Waspada Medan periode terbit bulan April tanggal 1, 4 dan 6 tahun 2019. Sumber Data penelitian ini adalah surat kabar Harian Waspada Medan periode terbitan bulan April tanggal 1, 4 dan 6 tahun 2019.

Teknik pengumpulan data dalam penelitian kajian pembentukan akronim pada Harian Waspada Medan ini menggunakan teknik membaca dan mencatat. Membaca berarti melakukan pengamatan pada teks berita yang terdapat akronim lalu mencatat data akronim tersebut. 
Sugiyono (2017) mengatakan, analisis data adalah proses mencari, menyusun secara sisitematis data yang diperoleh dari hasil wawancara, catatan lapangan, dan dekomentasi, dengan cara mengorganisasikan data ke dalam kategori, menjabarkan ke dalam unit-unit, melakukan sintesa, menyusun ke dalam pola, memilih mana yang paling penting dan akan dipelajari, dan membuat kesimpulansehingga mudah dipahami oleh diri sendiri dan orang lain.

Teknik penumpulan data dan analisis data denganlangkah-langkah yang dilakukan dalam teknik pengumpulan data adalah yaitu dengan, membaca isi berita pada surat kabar harian Waspada Medan, mencatat data akronim yang terdapat dalam berita pada harian Waspada Medan, melakukan pengelompokan data yang ditemukan ke dalam jenis pembentukan akronim, melakukan analisis dan mendeskripsikan data hasil temuan.

\section{HASIL DAN PEMBAHASAN}

Setelah dilakukan pengolahan data mulai dari pengumpulan data, pengelompokan data dan mendeskripsikan proses pembentukan akronim yang terdapat dalam surat kabar harian Waspada Medan. Hasil penelitian yang ditemukan dipaparkan sebagai berikut:

\section{Proses Pengekalan Suku dengan Suku}

Proses pengekalan suku dengan suku memiliki sepuluh tipe pembentukan akronim.Dalam penelitian ini terdapat empat proses pembentukan akronim diurutkan sesuai nomor sebagai berikut:

1. Proses pengekalan suku awal komponen pertama dan pengekalan suku awal komponen kedua, contoh:raker, casis, bimtek, kunker, sekjen, sekda.

3. Proses pengekalan suku awal komponen pertama dan pengekalan suku terakhir komponen kedua, misalprodi.

6. Proses pengekalan suku awal komponen pertama, kedua dan ketiga, misal:sekdako.

7. Proses pengekalan suku awal komponen pertama dan kedua, dan pengekalan suku terakhir komponen ketiga, misal:pasutri.

\section{Proses Pengekalan Suku dengan Suku dan Huruf}

Proses pengekalan suku dengan suku memiliki lima puluh delapan tipe pembentukan akronim.Dalam pengelompokan data ini terdapat dua puluh tiga tipe proses pembentukan akronim yang ditemukan sebagai berikut:

1. Proses pengekalan suku awal komponen pertama, pengekalan suku awal plus konsonan komponen kedua, misal:parpol, parlok, korwil, caleg , humas, kesos, jabar, capres, brimob, sekdes, pengkot, pengprov.

3. Proses pengekalan suku awal plus konsonan komponen pertama dan pengekalan suku awal komponen kedua, misal:golkar, jokdri, perda, pemko, kepri, musda, mayjen.

4. Proses pengekalan suku awal komponen plus konsonan, pengekalan suku awal komponen kedua plus konsonan, misal:calhaj, golput, pemkab, kopdar, kompol, sulsel, jaspel, kaltim, korsel, dinsos, reskrim, pemprov, dirut, akpol, unand, undip, korut, sulut, sumut, kombes, asprov. 
5. Proses pengekalan suku awal komponen pertama plus konsonan, pengekalan suku awal, suku tengah dari komponen kedua, misal:kominfo.

6. Proses pengekalan suku awal dari komponen pertama plus konsonan, pengekalan suku akhir komponen kedua, misal:satgas, paslon, pansus.

8. Proses pengekalan suku awal, suku tengah plus konsonan komponen pertama, pengekalan suku awal komponen kedua, misal:pemilu.

9. Proses pengekalan suku awal, suku tengah plus konsonan pada komponen pertama, dan pengekalan suku awal plus konsonan komponen kedua, misal:silatnas.

14. Proses pengekalan suku awal minus vokal, pengekalan suku akhir minus konsonan komponen pertama, pengekalan suku awal ditambah konsonan, misal:kades, kacab, kabag.

15. Proses pengekalan suku awal minus vokal, pengekalan suku akhir minus konsonan komponen pertama. Pengekalan suku awal minus vokal, pengekalan suku akhir komponen kedua, misal:kasi.

16. Proses pengekalan suku awal komponen pertama dan kedua, dan pengekalan suku awal plus konsonan komponen ketiga, misal:cawapres, rakorwil, tipikor, jalinsum, koramil

20. Proses pengekalan suku awal komponen pertama, pengekalan suku awal plus konsonan komponen kedua, dan pengekalan suku awal plus konsonan komponen ketiga, misal:tabagsel

24. Proses pengekalan suku awal komponen pertama, pengekalan suku awal minus konsonan komponen kedua dan pengekalan suku awal komponen ketiga, misal:IMKA.

25. Proses pengekalan suku awal komponen pertama, pengekalan suku awal minus vokal dan konsonan komponen kedua, dan pengekalan suku awal, suku tengah komponen ketiga, misal:apindo

26. Proses pengekalan suku awal plus konsonan komponen pertama, pengekalan suku awal komponen kedua, dan pengekalan suku awal plus konsonan komponen ketiga, misal:dirkrimum, kesbangpol

27. Proses pengekalan suku awal plus konsonan komponen pertama, pengekalan suku awal komponen ketiga, dan pengekalan suku awal minus konsonan komponen ketiga, misal:sergap.

28. Proses pengekalan suku awal plus konsonan komponen pertama, dan kedua dan pengekalan suku awal komponen ketiga, misal:gerindra.

32. Proses pengekalan suku awal plus konsonan komponen pertama, pengekalan suku awal minus konsonan komponen kedua, dan pengekalan suku awal minus vokal komponen ketiga, misal:unpab.

33. Proses pengekalan suku awal plus konsonan komponen pertama, pengekalan suku awal minus konsonan komponen kedua, dan pengekalan suku awal minus vokal dan konsonan komponen ketiga, misal:persit,ASLI.

35. Proses pengekalan suku awal minus konsonan komponen pertama, pengekalan suku awal komponen kedua dan ketiga, misal:banser.

46. Proses pengekalan suku akhir komponen pertama, pengekalan suku awal komponen kedua, dan pengekalan suku awal minus vokal komponen ketiga, misal:danrem.

51. Proses pengekalan suku awal minus konsonan, pengekalan suku akhir minus konsonan komponen pertama, pengekalan suku awal komponen kedua, dan 
pengekalan suku awal ditambah konsonan komponen ketiga, misal:kakanwil.

55. Proses pengekalan suku awal minus konsonan komponen pertama, pengekalan suku awal minus vokal, pengekalan suku tengah minus vokal dan konsonan komponen kedua, pengekalan suku awal komponen pertama, misal:poskamling.

57. Proses pengekalan suku awal komponen pertama, pengekalan suku awal minus vokal komponen kedua, dan pengekalan suku awal, pengekalan suku tengah komponen ketiga, misal:paluta.

\section{Proses Pengekalan Kata, suku dan Huruf}

Proses pengekalan kata atau komponen penuh dengan suku dan huruf memiliki lima tipe pembentukan akronim.Dalam pengelompokan data ini terdapat satu tipe proses pembentukan akronim yang ditemukan sebagai berikut:

1. Proses pengekalan komponen pertama penuh dengan pengekalan suku awal komponen kedua, misal:Jokowi.

\section{Proses Pelesapan Kata, Suku dan Huruf}

Proses pelesapan kata atau komponen penuh dengan suku memiliki empat tipe pembentukan akronim, dalam pengelompokan data ini terdapat dua tipe pembentukan akronim yang ditemukan sebagai berikut:

1. Proses pengekalan suku awal komponen pertama dan kedua dan pelesapan komponen ketiga, misal:menlu.

4. Proses pengekalan suku awal, suku tengah komponen pertama, pelesapan komponen kedua, pengekalan suku awal ditambah konsonan komponen ketiga, misal:ikanas, unimed.

\section{Proses Pengekalan Huruf Awal}

Proses pengekalan huruf awal memiliki tiga tipe pembentukan akronim, dalam pengelompokan data ini terdapat tiga tipe pembentukan akronim yang ditemukan sebagai berikut:

1. Proses pengekalan huruf awal dari komponen pertama, kedua dan ketiga, misal:USU, FIB, PON, UAS, MIN, MAN, MAS, HAM, PAN, UMA, BOS, UDA, KUA.

2. Proses pengekalan huruf awal dari komponen pertama, kedua, ketiga, dan empat, misal:UMSU, FOPI, KONI, PAUD, KANA, UISU, MIPA, YARA.

3. Proses pengekalan huruf awal dari komponen pertama, kedua, ketiga, keempat dan kelima, misal:KAHMI, UINSU, FISIP, BAN PT, PAN RB, PODSI.

Proses pembentukan akronim merupakan tahapan bagaimana akronim itu dibentuk. Untuk proses pembentukan akronim dibutuhkan pengekalan suku dalam pembentukannya. Yaitu mengekalkan bagian-bagian komponen pada bagian yang dikekalkan dari setiap bagian komponen ke bagian komponen berikutnya menjadi terbentuklah sebuah akronim. Pada proses pembentukan akronim ini bertumpu pada pengekalan suku, huruf, dan kata. Dapat dideskripsikan pada penelitian ini terdapat lima proses pembentukan akronim.

Pertama, proses pembentukan akronim dibentuk dengan proses pengekalan suku dengan suku dari setiap komponen. Seperti contoh akronim bimtekyaitu bimbingan 
teknis memiliki dua komponen. Akronim bimtek ini memiliki proses pengekalan suku awal bimkomponen pertamadan pengekalan suku awal tekkomponen kedua.

Kedua, proses pembentukan akronim dibentuk melalui proses pengekalam suku dengan suku dan huruf dari setiap komponen. Dalam proses pengekalan ini juga terjadi pengekalan suku plus konsonan atau vokal, minus konsonan atau vokal. Seperti contoh akronim capres yaitu calon presiden yang memiliki dua komponen. Proses pengekalan capres ini dibentuk pengekalan suku awal komponen pertama $\mathrm{ca}$ dan pengekalan suku awal preplus konsonan skomponen kedua.

Ketiga, proses pembentukan akronim dibentuk melalui proses pengekalan kata atau komponen penuh, dengan suku dan huruf. Proses pembentukan ini dilakukan dengan pengekalan salah satu komponen penuh dengan pengekalan suku dan huruf. Contoh akronim, jokowi yang berarti joko widodo, yakni proses pengekalan komponen penuh komponen pertama joko dan pengekalan suku awal wikomponen kedua.

Keempat, proses pembentukan akronim dibentuk melaui proses pelesapankata atau komponen penuh dengan suku dan huruf. Contoh akronim unimed yaitu universitas negeri medan. Proses pengekalan suku awal $u$, suku tengah ni komponen pertama, pelesapan komponen kedua negeri, dan pengekalan suku awal me plus konsonan $d$ komponen ketiga.

Kelima, proses pembentukan akronim dibentuk melalui proses pengekalan huruf awal setiap komponen. Contoh akronim ham yaitu hak asasi manusia, proses pengekalan huruf pertama $h$ komponenpertama pengekalan huruf pertama akomponen kedua, pengekalan huruf pertama $m$ komponen ketiga.

\section{KESIMPULAN}

Setelah pengelompokan data dilakukan terdapat lima pola proses pembentukan akronim yaitu (1) Pengekalan suku dengan suku terdapat empat proses(2) Pengekalan suku ditambah huruf terdapat dua puluh tiga proses(3) Pengekalan kata dengan suku terdapat satu proses(4) Pelesapan kata dengan suku dan huruf terdapat dua proses(5) Pengekalan huruf awal setiap komponen terdapat tiga proses dan tidak ditemukan data untuk proses pengekalan huruf awal dengan suku.

Perlunya penelitian lanjutan berkaitan tentang akronim ini agar semakin menambah pengetahuan keilmuan bahasa. Pemakai bahasa diharapkan menggunakan akronim secara bijaksana sesuai dengan kebutuhan berbahasa dan membuat akronim dalam kebutuhan bahasa diharapkan sesuai kaidah yang berterima. Bahasa merupakan harta yang berharga maka perlu dilestarikan karena keutuhan bahasa menjadikan manusia sejahtera.

\section{REFERENSI}

Badudu, J.S. (1993). Cakrawala Bahasa Indonesia I. Jakarta: Gramedia Pustaka Utama. Chaer, Abdul. (2008). Morfologi Bahasa Indonesia. Jakarta: Rineka Cipta.

Deliani, Susy. (2013). Pola Akronim dalam Bahasa Indonesia. Disertasi. Program Pascasasrjana Linguistik USU, Medan.

Depdiknas. (2013). Kamus Besar Bahasa Indonesia. Jakarta: Badan Bahasa 
Kridalaksana, Harimurti. (1996). Pembentukan Kata Dalam Bahasa Indonesia. Jakarta: Gramedia Pustaka Utama.

Moeleong, Lexy J. (2017). Metodologi Penelitian Kualitatif. Bandung: Remaja Rosda Karya.

Moeliono, Anton. (1988). Tata Bahasa Baku Bahasa Indonesia. Jakarta: Dapartemen Pendidikan dan Kebudayaan.

Nugraheni, Sri Aninditya. (2017). Bahasa Indonesia Untuk Perguruan Tinggi Berbasis Pembelajaran Aktif. Jakarta: Kencana.

Purwanto, A \& Markhamah. (2019). Language Error Analysis In Mpbi-Ums Students Speech Who Roled As Police Officers. Aksis: Jurnal Pendidikan Bahasa dan Sastra Indonesia 3(1). 118-128. doi: doi.org/10.21009/AKSIS.030112.

Sirait, Ernawati. (2015). Analisis Antologi Puisi Menyimak Ayat Ombak Karya Syafwan Hadi Umry dari Aspek Sosiologi. Tesis. Program Pascasarjana Pendidikan Bahasa Indonesia UMN, Medan.

Sugiyono. (2017). Metode Penelitian Pendidikan, Pendekatan Kuantitatif, Kualitatif dan $R \& D$. Bandung: Alfabeta.

Waridah, Ernawati. (2016). PUEBI dan Seputar Kebahasa-Indonesiaan. Bandung: Ruang Kata.

Zaim, M. (2015). Pergeseran Sistem Pembentukan Kata Bahasa Indonesia: Kajian Akronim, Blending dan Kliping. Masyarakat Lingiuistik Indonesia. Jurnal. 